\title{
Economic impacts of a glacial period: a thought experiment to assess the disconnect between econometrics and climate sciences
}

\author{
Marie-Noëlle Woillez ${ }^{1}$, Gaël Giraud ${ }^{2,3,4}$, and Antoine Godin ${ }^{1,5}$ \\ ${ }^{1}$ Agence Française de Développement, 5 rue Roland Barthes, 75012 Paris, France \\ ${ }^{2}$ Georgetown Environmental Justice Program, Georgetown University, \\ 37th and O Streets N.W., Washington D.C. 20057, USA \\ ${ }^{3}$ Centre d'Economie de la Sorbonne, Paris 1 University Panthéon-Sorbonne, \\ 106-112 bd. de l'Hôpital, 75013 Paris, France \\ ${ }^{4}$ Chair Energy \& Prosperity, Institut Louis bachelier, 28 place de la Bourse, 75002 Paris, France \\ ${ }^{5}$ Centre de recherche en Économie et gestion de Paris Nord, Université Sorbonne Paris Nord, \\ 99 avenue Jean-Baptiste Clément, 93430 Villetaneuse, France
}

Correspondence: Marie-Noëlle Woillez (woillezmn@afd.fr)

Received: 15 May 2020 - Discussion started: 27 May 2020

Revised: 28 August 2020 - Accepted: 14 September 2020 - Published: 4 December 2020

\begin{abstract}
Anthropogenic climate change raises growing concerns about its potential catastrophic impacts on both ecosystems and human societies. Yet, several studies on damage induced on the economy by unmitigated global warming have proposed a much less worrying picture of the future, with only a few points of decrease in the world gross domestic product (GDP) per capita by the end of the century, even for a global warming above $4{ }^{\circ} \mathrm{C}$. We consider two different empirically estimated functions linking GDP growth or GDP level to temperature at the country level and apply them to a global cooling of $4{ }^{\circ} \mathrm{C}$ in 2100 , corresponding to a return to glacial conditions. We show that the alleged impact on global average GDP per capita runs from $-1.8 \%$, if temperature impacts GDP level, to $+36 \%$, if the impact is rather on GDP growth. These results are then compared to the hypothetical environmental conditions faced by humanity, taking the Last Glacial Maximum as a reference. The modeled impacts on the world GDP appear strongly underestimated given the magnitude of climate and ecological changes recorded for that period. After discussing the weaknesses of the aggregated statistical approach to estimate economic damage, we conclude that, if these functions cannot reasonably be trusted for such a large cooling, they should not be considered to provide relevant information on potential damage in the case of a warming of similar magnitude, as projected in the case of unabated greenhouse gas emissions.
\end{abstract}

\section{Introduction}

Since the first Intergovernmental Panel on Climate Change (IPCC, 1990) report, anthropogenic climate change has been the subject of large research efforts. Increased knowledge has raised growing concerns about its potential catastrophic impacts on both ecosystems and human societies if greenhouse gas (GHG) emissions continue unmitigated. In addition to the worsening of mean climate conditions in many places, numerous studies emphasize the risks associated with increased frequency and/or magnitude of extreme events (e.g., droughts, heat waves, storms, floods), rising sea level, and glacier melting (IPCC, 2013). These risks have drawn attention to potential catastrophic consequences for the world economy (Weitzman, 2012; Dietz and Stern, 2015; Bovari et al., 2018). Yet, several other studies on damage induced on the world economy by unmitigated global warming have proposed a much less worrying picture of the future, with 
economic damage limited to only a few points of the world gross domestic product (GDP) ${ }^{1}$ (see Tol, 2018, for a review). Some authors could even conclude that "a century of climate change is likely to be no worse than losing a decade of economic growth" and hence that "there are bigger problems facing humankind than climate change" (Tol, 2018, p. 6). Such results seem surprising when compared to the conclusions of the last IPCC report (IPCC, 2013) and to various rather alarming publications since then (Hansen et al., 2016; Mora et al., 2017; Steffen et al., 2018; Nolan et al., 2018). Damage functions ${ }^{2}$, at the heart of many macroeconomic analyses of climate change impacts, have, however, been heavily criticized for their lack of empirical or theoretical foundations and for their inadequacy to evaluate the impact of climate change outside the calibration range (Pindyck, 2013, 2017; Pottier, 2016; Pezzey, 2019).

Here, we want to further highlight the disconnect between climate sciences and economic damage projected at the global scale, focusing on econometric approaches. To do so, two different strategies could be considered.

- Carefully list all the climate and environmental changes, as described by climate models for the end of the century (including extreme events, sea level rise, etc.) that are not accounted for by such damage functions and show that the damage would be much larger than the projections obtained with these functions, as done by DeFries et al. (2019) for assessments of climate change damage in general. This option would strongly rely on projections from current Earth system models and there are still many uncertainties, especially on potential tipping points in the climate system.

- Apply some econometric methods to a different, but rather well-known, past climate change for which not only results from climate models are available, but also various climate and environmental proxy data, and discuss the plausibility or implausibility of the results.

We investigate this latest option, choosing the Last Glacial Maximum (LGM, about 20000 years ago) as a test past period. On the one hand, the global temperature increase projected by 2100 for unabated GHG emissions (scenario RCP8.5, Riahi et al., 2011) is indeed roughly of the same amplitude, though of opposite sign, as the estimated temperature difference between the preindustrial period and the LGM, which is about $4{ }^{\circ} \mathrm{C}$ (IPCC, 2013). The magnitude of climatic and environmental changes during the last glacial-tointerglacial transition can thus provide an index of the magnitude of the changes that may occur for a warming of similar amplitude in 2100 , as already postulated by Nolan et al.

\footnotetext{
${ }^{1}$ World GDP is probably a misnomer, as we should rather refer to global world product instead. We will nonetheless retain the common usage of "world GDP".

${ }^{2}$ The term damage function refers to the formal relation between climatic conditions and economic impacts at the global level.
}

(2018). On the other hand, by design, statistical relationships linking climatic variables to economic damage could be applied either to a warming or to a cooling. Therefore, we test two of them for a hypothetical return to the LGM, except for the presence of northern ice sheets (see Sect. 5), corresponding to a global cooling of $4{ }^{\circ} \mathrm{C}$ in 2100 .

We chose two statistical functions linking GDP and temperature at the country level: the first one has been introduced by Burke et al. (2015) and formalizes the impact of temperature on country GDP growth; the second one by Newell et al. (2018) relates temperature to country GDP level ${ }^{3}$. The strength of this exercise lies in our ability to counter-check the results on potential damage under scrutiny with reconstructions from paleoclimatology.

The paper is structured as follows: Sect. 2 briefly surveys the existing literature on climate change and economic damage; Sect. 3 presents the methodology and data used here. The next section then describes the results obtained for our cooling scenario, and Sect. 5 compares these results with what is known of the Earth under such a climate situation. Section 6 then discusses our results in light of the known strengths and weaknesses of such empirical functions, while Sect. 7 concludes.

\section{Connecting climate change and economic damage}

The literature on the broad topic of damage functions (see Tol, 2018, for a review) can be organized into two main approaches linking climate change to economic damage: an enumerative approach, which estimates physical impacts at a sectorial level from natural sciences, gives them a price, and then adds them up (e.g., Fankhauser, 1994; Nordhaus, 1994b; Tol, 2002), versus a statistical (or econometric) approach based on observed variations of income across space or time to isolate the effect of climate on economies (e.g., Nordhaus, 2006; Burke et al., 2015).

Each method has its pros and cons, some of which have already been acknowledged in the literature.

- The main advantage of the enumerative approach is that it is based on natural sciences experiments, models, and data (Tol, 2009). It distinguishes between the different economic sectors and explicitly accounts for climate impacts on each of them. Yet, results established for a small number of locations and for the recent past are usually extrapolated to the world and to a distant future in order to obtain global estimates of climate change impacts. The validity of such extrapolation remains dubious, and it can lead to large errors. Moreover, accounting for potential future adaptations is a real challenge

\footnotetext{
${ }^{3}$ Both Burke et al. (2015) and Newell et al. (2018) then create a world GDP value via a population-weighted average of the country GDP.
} 
and therefore a major source of uncertainty in the projections. This method also implies being able to correctly identify all the different channels through which climate affects the economy, which is by no means an easy task. And finally, it does not take into account interactions between sectors or price changes induced by changes in demand or supply (Tol, 2018).

- The statistical approach has the major advantage of relying on aggregates such as GDP per capita. There is no need to identify the different types of impacts for each economic sector and to estimate their specific costs. They rely on a limited number of climatic variables, such as temperature and precipitation, which are used as a proxy for the different climatic impacts. Adaptation is also implicitly taken into account, at least to the extent that it already occurred in the past. But as acknowledged by Tol (2018), one of the main weakness of some statistical approaches is that they use variations across space to infer climate impacts over time. This method also shares with the enumerative one the disadvantage of using only data from the recent past and hence from a period with a small climate change. The issue of future climatic impacts outside the calibration range of the function still remains.

Despite different underlying methodological choices, several studies investigating future climatic damage conclude that global warming would cost only a few points of the world's income (Tol, 2018). A $3{ }^{\circ} \mathrm{C}$ increase in the global average temperature in 2100 would allegedly lead to a decrease in the world's GDP by only $1 \%-4 \%$. Even a global temperature increase above $5{ }^{\circ} \mathrm{C}$ is claimed by certain authors to cost less than $7 \%$ of the world future GDP (Nordhaus, 1994a; Roson and Van der Mensbrugghe, 2012).

Some statistical studies looking at GDP growth (e.g., Dell et al., 2012; Burke et al., 2015) emphasize the long-run consequences and lead to higher damage projections than those previously mentioned. In particular, Burke et al. (2015) (hereafter BHM) evaluate the impact of global warming on growth at the country scale using temperature, precipitation, and GDP data for 165 countries over 1960-2010. According to their benchmark model, the temperature increase induced by strong GHG emissions (scenario RCP8.5) would reduce average global income by roughly $23 \%$ in 2100 . This relatively high figure, however, is a decrease in potential GDP, itself identified with the projected growth trajectory according to Shared Socioeconomic Pathway 5 (SSP5, high growth rate; Kriegler et al., 2017). As a result, under a global temperature increase of about $4{ }^{\circ} \mathrm{C}$, only $5 \%$ of countries would be poorer in 2100 with respect to today, and world GDP would still be higher than today. It must be noted that these results strongly depend on the underlying baseline scenario: if a lower reference growth rate is assumed (SSP3), the percentage of countries absolutely poorer in 2100 rises to $43 \%$.
Capturing the impact of warming on growth rather than on GDP level may appear more realistic. Indeed, it allows global warming to have permanent effects and also accounts for resource consumption to counter the impacts of warming, reducing investments in $\mathrm{R} \& \mathrm{D}$ and capital and hence economic growth (Pindyck, 2013). There is, however, no consensus on the matter. In a recent work, Newell et al. (2018) (hereafter NPS) evaluate the out-of-sample predictive accuracy of different econometric GDP-temperature relationships at the country level through cross-validation and conclude that their results favor models with nonlinear effects on GDP level rather than growth, implying, for their statistically best fitted model, world GDP losses due to unmitigated warming of only $1 \%-2 \%$ in 2100 .

Studies on future climate change damage to the global economy usually do not pretend to account for all possible future impacts. This is obvious for the enumerative methods applied at the global scale: being exhaustive is not realistically feasible. But this is also true for statistical approaches. Nordhaus (2006), for instance, gives three major caveats to his statistically based projections of climate change damage: (1) the model is incomplete; (2) estimates do not incorporate any nonmarket impacts or abrupt climate change, especially on ecosystems; and (3) the climate-economy equilibrium hypothesis used is highly simplified. Burke et al. (2015) also acknowledge that their econometric model only captures effects for which historical temperature has been a proxy. Yet, despite these major caveats, results from both approaches are widely cited as "climate change" damage estimates (Carleton and Hsiang, 2016; Hsiang et al., 2017), as if they were really accounting for the whole range of future impacts, and some are used to estimate the so-called social cost of carbon (Tol, 2018). The authors themselves do not always clearly distinguish "climate change" impacts, which in the strict sense of the term should be applied to exhaustive estimates, from the non-exhaustive impacts accounted for by the specifically chosen proxy variable.

In our view, in addition to this common semantic confusion, at least two of the aforementioned caveats are highly problematic: (1) extrapolating relationships outside their calibration range (which concerns both enumerative and statistical methods) and (2) known and unknown missing impacts for which the chosen predicting climatic variables are not good explanatory variables. The fact that the channels of damage are not explicit in the statistical approach is convenient but also rather concerning: we simply cannot know which impacts are missed, except for a few of them (e.g., sea level rise).

A global warming of $4{ }^{\circ} \mathrm{C}$ at the end of the century would drive the global climatic system to a state that has never been experienced in the whole of human history, with growing concerns about the potential nonlinearities in the way the Earth system as a whole may evolve: ecosystems have tipping points (e.g., Hughes et al., 2017; Cox et al., 2004); the ice loss from the Greenland and Antarctic ice sheets has 
already clearly accelerated since the middle of the 2000s (Bamber et al., 2018; Shepherd et al., 2018); the projected wet-bulb temperature rise in the tropics could reach levels that do not presently occur on Earth and that would simply be above the threshold for human survival (Im et al., 2017; Kang and Eltahir, 2018). Thus, the question is the following: to what extent are we missing the point when using aggregated statistical approaches to estimate future damage?

One could argue that we are not so sure about what a $4{ }^{\circ} \mathrm{C}$ warmer planet would look like, since we lack any analog from the recent past. Yet, we actually have an example of a climate change of similar magnitude, albeit of a different sign: the last glacial period. In this paper, we focus on two representative examples of the statistical approach, the BHM and NPS functions, and use the LGM climate to test their relevance to assess the damage expected from a large and rapid climate change.

The choice of these two functions was based on the following considerations.

- While there might be controversies regarding the paper of Burke et al. (2015) related to the model specifications, interpretation, and statistical significance of the results or even the validity of the approach, the approach is well-published in leading peer-reviewed journals. Their work has been widely cited in the literature and has been used to compute the social cost of carbon (e.g., Ricke et al., 2018). The authors also published several other papers based on similar methodologies (e.g., Hsiang, 2016; Burke et al., 2018; Diffenbaugh and Burke, 2019).

- The function of Newell et al. (2018) has not been published in a peer-reviewed journal ${ }^{4}$, but we considered it anyway because (1) it belongs to the family of damage functions assuming an impact of climate on GDP level rather than growth, leading to very little damage, and (2) it is based on the same data and methodology as Burke et al. (2015), hence simplifying the exercise.

We decided to perform an ad absurdum demonstration of the strong limitations of such approaches because we believe that it is a useful complementary contribution to a more mathematical and statistical critique, which is not our purpose here. As documented by DeCanio (2003) for older functional forms, the literature on damage functions has had tremendous political implication and even found its way into IPCC reports. Therefore, we believe it is important to add new elements to the existing critiques.

We chose to focus on the statistical approach because it inherently includes the effect of both cooling and warming. This is not the case for enumerative approaches, which are

\footnotetext{
${ }^{4}$ The paper can be downloaded here: https://media.rff. org/archive/files/document/file/RFFWP-18-17-rev.pdf (last access: 17 November 2020).
}

primarily designed for a warming and could not be applied to a cooling. They may nonetheless lead to implausible results as well, especially at the global scale (see the aforementioned caveats), but illustrating the disconnect between their damage projections and climate sciences would have required a different approach than the one we use here (e.g., questioning their assumptions sector by sector or providing damage estimates for impacts not taken into account).

\section{Material and methods}

In order to assess the economic damage of a hypothetical return to an ice age, we compute the evolution of average GDP per capita by country with or without the corresponding global cooling, following the methodology described in BHM using the replication data provided with their publication. Details are available therein. We differ from BHM in two ways.

- For the simplicity of the demonstration, we chose to consider only one functional form linking temperature to GDP from BHM and NPS: we use either the BHM formula with their main specification (temperature impacts GDP growth, pooled response, short-run effect), whose results are the most commented on in their paper, or the preferred specification of NPS (temperature impacts GDP level, best model by $K$-fold validation; full details in Newell et al., 2018).

- Our climate change scenario corresponds to a global cooling of $4{ }^{\circ} \mathrm{C}$, based on LGM temperature reconstructions and assuming a linear temperature decrease, instead of the climate projections for the RCP8.5 scenario. Following BHM, who consider only temperature projections for the assessment of future damage, we do not use LGM precipitation reconstructions.

Criticism of potential mathematical development, variable choices, or data issues in the BHM or NPS work is beyond the scope of this paper. Our aim is limited to using their respective base equations as they are to test their realism for a large climate change scenario. Following BHM, we also use the socioeconomic scenario SSP5 as a benchmark for future GDP per capita growth per country. SSP5 is supposed to be consistent with the GHG emission scenario RCP8.5, but it does not include any climate change impact, even for high levels of warming. Therefore, we can still use it in our glacial scenario without inconsistency.

The base case of BHM links the population-weighted mean annual temperature to GDP growth at the country level. Their model uses the following functional form:

$\Delta \ln \left(\operatorname{GDPcap}_{i, t}\right)=f\left(T_{i, t}\right)+g\left(P_{i, t}\right)+\mu_{i}+v_{t}+h_{i}(t)+\varepsilon_{i, t}$,

where $\Delta \ln \left(\operatorname{GDPcap}_{i, t}\right)$ denotes the first difference of the natural $\log$ of annual real GDP per capita, i.e., the per-period 
growth rate in income for year $t$ in country $i, f\left(T_{i, t}\right)$ is a function of the mean annual temperature, $g\left(P_{i, t}\right)$ a function of the mean annual precipitation, $\mu_{i}$ a country-specific constant parameter, $v_{t}$ a year fixed effect capturing abrupt global events, and $h_{i}(t)$ a country-specific function of time accounting for gradual changes driven by slowly changing factors. BHM control for precipitation in Eq. (1) because changes in temperature and precipitation tend to be correlated. Rather surprisingly, their study does not show a statistically significant impact of annual mean precipitation on per capita GDP.

In their base case model, $f\left(T_{i, t}\right)$ is defined as

$f\left(T_{i, t}\right)=\alpha_{1} \times T_{i, t}+\alpha_{2} \times T_{i, t}^{2}$.

Based on historical data, they determined the coefficient values to be $\alpha_{1}=0.0127$ and $\alpha_{2}=-0.0005$.

Future evolution of GDP per capita in country $i$ and year $t$ between 2010 and 2100 is then given by

GDPcap $_{i, t}=$ GDPcap $_{i, t-1} \times\left(1+\eta_{i, t}+\delta_{i, t}\right)$,

with $\eta_{i, t}$ the business-as-usual country growth rate without climate change, according to SSP5 (taking into account population changes), and $\delta_{i, t}$ the additional effect of temperature on growth when the mean annual temperature differs from the reference average over 1980-2010, $T_{i, \text { ref: }}$ :

$\delta_{i, t}=\alpha_{1} \times\left(T_{i, t}-T_{i, \text { ref }}\right)+\alpha_{2} \times\left(T_{i, t}^{2}-T_{i, \text { ref }}^{2}\right)$.

It should be noted that BHM do not take into account precipitation changes in their projection of future GDP.

The income growth-temperature relationship is a concave function of $T_{i, t}$, with an optimum temperature around $13{ }^{\circ} \mathrm{C}$ (Fig. 1). Therefore, for a country with a reference mean annual temperature below this value that maximizes GDP per capita (e.g., Iceland), the annual growth rate increases (decreases) when the mean temperature increases (decreases). This relationship is reversed for countries with a reference temperature above the optimum value (e.g., Nigeria). Note that for countries already close to the optimum temperature (like France), a small temperature change will have a very limited impact on per capita GDP growth, but any major temperature change of several degrees, whatever the sign, will move them away from this optimum and have a negative impact on per capita GDP growth.

The preferred model of NPS links the mean annual temperature to the per capita GDP level based on the same historical sample as BHM and excludes any precipitation component. It links GDP in country $i$ at year $t$ to a polynomial function of mean annual temperature:

$\ln \left(\operatorname{GDPcap}_{i, t}\right)=\beta_{1} \times T_{i, t}+\beta_{2} \times T_{i, t}^{2}+\ldots$.

Based on historical data, the authors determined the coefficient values to be $\beta_{1}=0.008141$ and $\beta_{2}=-0.000314$.

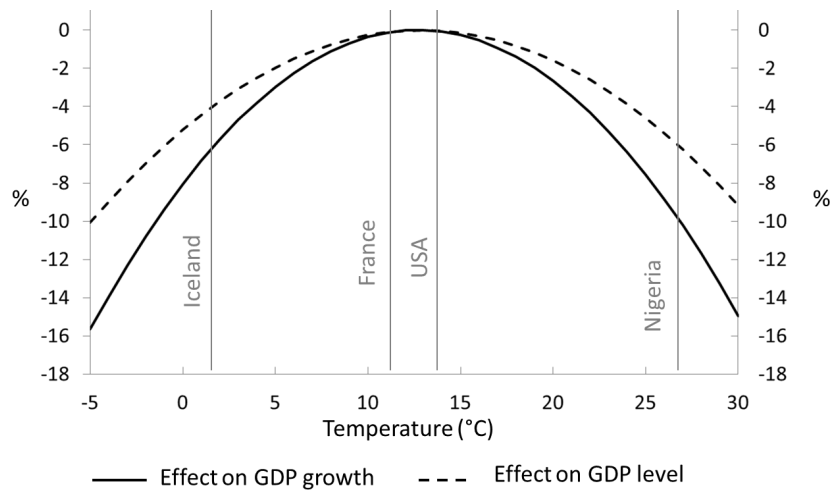

Figure 1. GDP per capita-temperature relationships, growth (BHM), and level (NPS) effects (percentage points). The curves are shown on the same plot but are not directly comparable, since their respective impact on GDP is fundamentally different. Vertical lines indicate average temperature for four selected countries. Each curve has been normalized relative to its own peak.

Using this formula, the future GDP per capita with climate change for the 21 st century, GDPcap $i, t$, is expressed as

$$
\begin{aligned}
\operatorname{GDPcap}_{i, t} & =\operatorname{GDPcap}_{i, t}^{*} \times \exp \left[\beta_{1} \times\left(T_{i, t}-T_{i, \text { ref }}\right)\right. \\
& \left.+\beta_{2}\left(T_{i, t}^{2}-T_{i, \text { ref }}^{2}\right)\right]
\end{aligned}
$$

with GDPcap $p_{i, t}^{*}$ being the GDP per capita of the country without climate change, according to SSP5:

$\operatorname{GDPcap}_{i, t}^{*}=\operatorname{GDPcap}_{i, t-1}^{*} \times\left(1+\eta_{i, t}\right)$.

The NPS GDP-temperature relationship is also a concave function of $T_{i, t}$, with an optimum temperature around $13{ }^{\circ} \mathrm{C}$ (Fig. 1). The shape is therefore similar to BHM, but the function is conceptually different since the impact of temperature is on the GDP level instead of its growth rate. The SSP5 growth rate $\eta_{i, t}$ remains unaffected by climatic conditions, and any negative temperature impact on year $t$ has no impact on the GDP per capita level at year $t+1$, which depends only on the underlying SSP5 scenario and on the temperature at year $t+1$.

To build our "glacial" scenario, we assume a linear decrease in temperature between 2010 (the end of the reference period) and the glacial state projected for 2100 . For any year $t>2010$, the country-specific mean temperature is therefore computed as

$T_{i, t}=\Delta T_{i} \times \frac{t-2010}{2100-2010}+T_{i, \text { ref }}$,

with $\Delta T_{i}$ the population-weighted temperature anomaly of country $i$ at the LGM computed from Annan and Hargreaves (2013) (Fig. 2).

Similarly to Burke et al. (2015), who cap $T_{i, t}$ at $30^{\circ} \mathrm{C}$, the upper bound of the annual average temperature observed in 


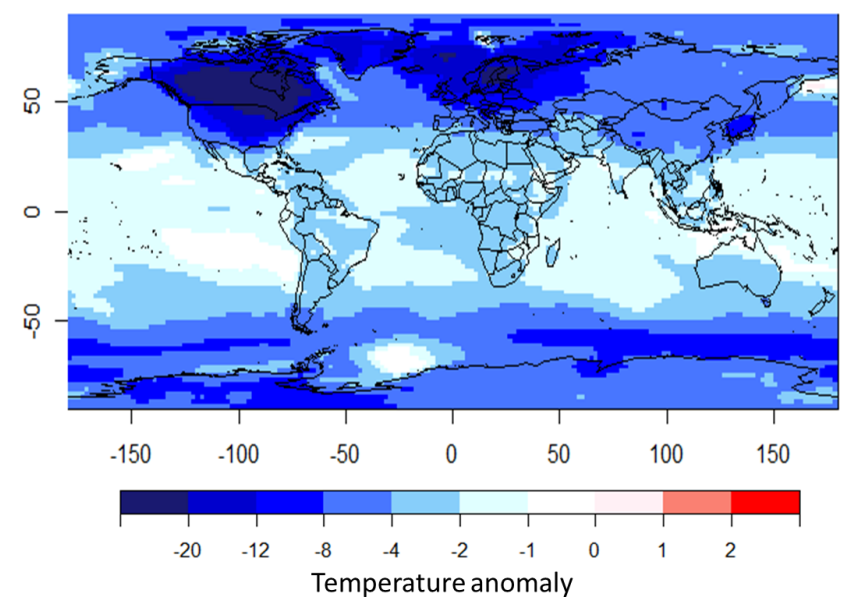

Figure 2. Reconstruction of the Last Glacial Maximum surface air temperature anomalies $\left({ }^{\circ} \mathrm{C}\right)$ based on multi-model regression. Data source: Annan and Hargreaves (2013).

their sample period, to avoid out-of-sample extrapolation, we cap the minimum possible value of $T_{i, t}$ at the lower bound of observations $\left(-5^{\circ} \mathrm{C}\right)$.

\section{GDP projections}

All results are expressed as distance from the baseline potential GDP based on the baseline SSP5 scenario, which assumes no climate change. The impact on world average GDP per capita is a population-weighted average of country-level impacts.

Using the NPS specification, in $2100,34 \%$ of the countries have a lower income per capita than without glacial climate change, but no country is poorer than today. The strongest impacts on GDP are projected in northern countries: Canada and Norway, for instance, exhibit a potential GDP loss of about $8 \%$. But at the global scale, the GDP loss projected in the northern countries is more than compensated for by a 1\%-2\% GDP gain in most of the southern countries (Fig. 4a). All in all, the impact of the temperature decrease on the world potential GDP is very limited, only about $-1.8 \%$ in 2100 (Fig. 3).

With the BHM specification, projected impacts are much more severe in northern countries: in the United States, Canada, Russia, and most of Europe GDP decreases range from $80 \%$ to nearly $100 \%$ in 2100 ; i.e., the impact of temperature on potential GDP growth is so large that it leads to a complete economic collapse (Figs. $4 \mathrm{~b}$ and 5). Similarly, stronger positive effects are projected in southern countries, with a large increase in GDP for most of them in 2100 (Fig. 4 b): e.g., $+254 \%$ in Gabon, $+314 \%$ in Ghana, $+267 \%$ in India, $+300 \%$ in Laos, $+366 \%$ in Mali, and $+400 \%$ in Thailand. China is the sole country where potential GDP remains roughly unchanged, with impacts smaller than $1 \%$. Globally, $31 \%$ of countries exhibit lower income per capita

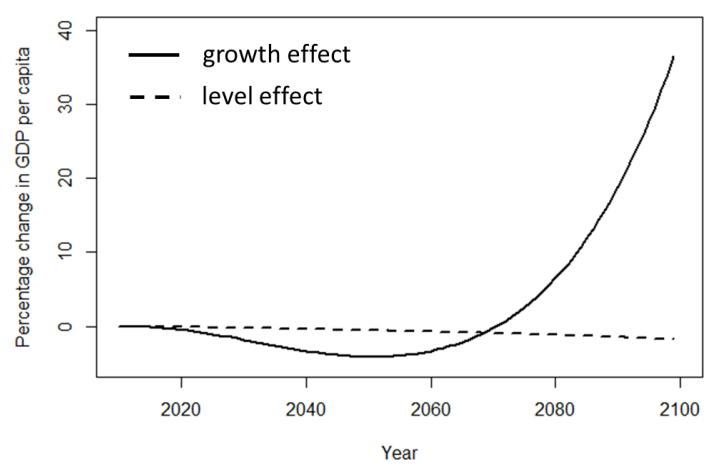

Figure 3. Percentage change in average world GDP per capita for a global cooling of $4{ }^{\circ} \mathrm{C}$ in 2100 as projected from nonlinear effects of temperature on GDP level (dashed line; Newell et al., 2018, specification) or growth (plain line; Burke et al., 2015, specification). Reference GDP path according to the SSP5 scenario.

than projected without climate change and $17 \%$ are poorer than today. Losses in northern countries drive a decrease in the world GDP during the first half of the century, with maximal global damage around 2050 at about $-4 \%$. In the second half, however, positive impacts in southern countries more than overcompensate for damage in the north, and as a consequence average potential GDP per capita gains $36 \%$ in 2100 at the world level with respect to the baseline scenario (Fig. 3).

\section{Comparison with LGM conditions}

To assess the credibility of these results we now survey the environmental conditions that human beings would have to face on our planet in 2100 under our theoretical scenario, taking what is currently known of the LGM as a reference and considering both climate and ecosystem changes. Ecosystem changes were then driven by both climate change and the impacts of low atmospheric $\mathrm{CO}_{2}$ concentrations on photosynthetic rates and plant water-use efficiency (Jolly and Haxeltine, 1997; Cowling and Sykes, 1999; Harrison and Prentice, 2003; Woillez et al., 2011), but, in order to simplify our argument, we do not distinguish between these two effects in our description of a world cooled by $4{ }^{\circ} \mathrm{C}$.

Many reconstructions of the climatic and environmental conditions during the LGM are available (Kucera et al., 2005; Bartlein et al., 2011; Prentice et al., 2011; Nolan et al., 2018; Clark et al., 2009), as are numerous modeling exercises (Braconnot et al., 2007; Kageyama et al., 2013, 2018; Annan and Hargreaves, 2013). Despite remaining uncertainties and discrepancies, data-based reconstruction and modeling results provide a fairly good picture of the Earth at that time.

The most striking feature of the last glacial world is the existence of large and thick ice sheets in the Northern Hemisphere (Peltier, 2004; Clark et al., 2009). Of course, reaching the full extent of the LGM ice sheets, which depends 
(a) Level impacts

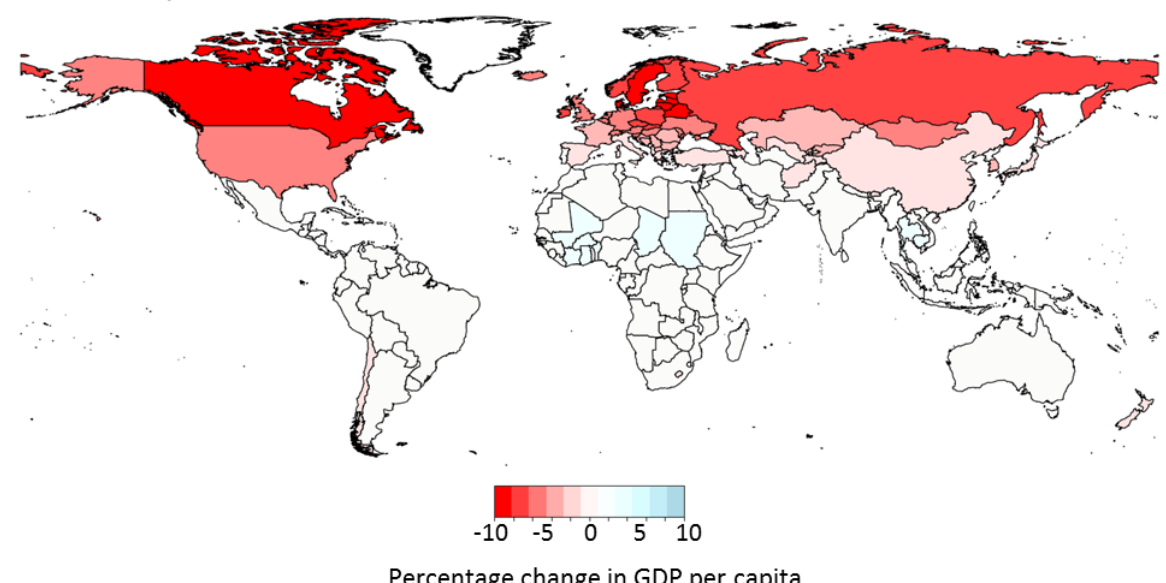

(b) Growth impacts

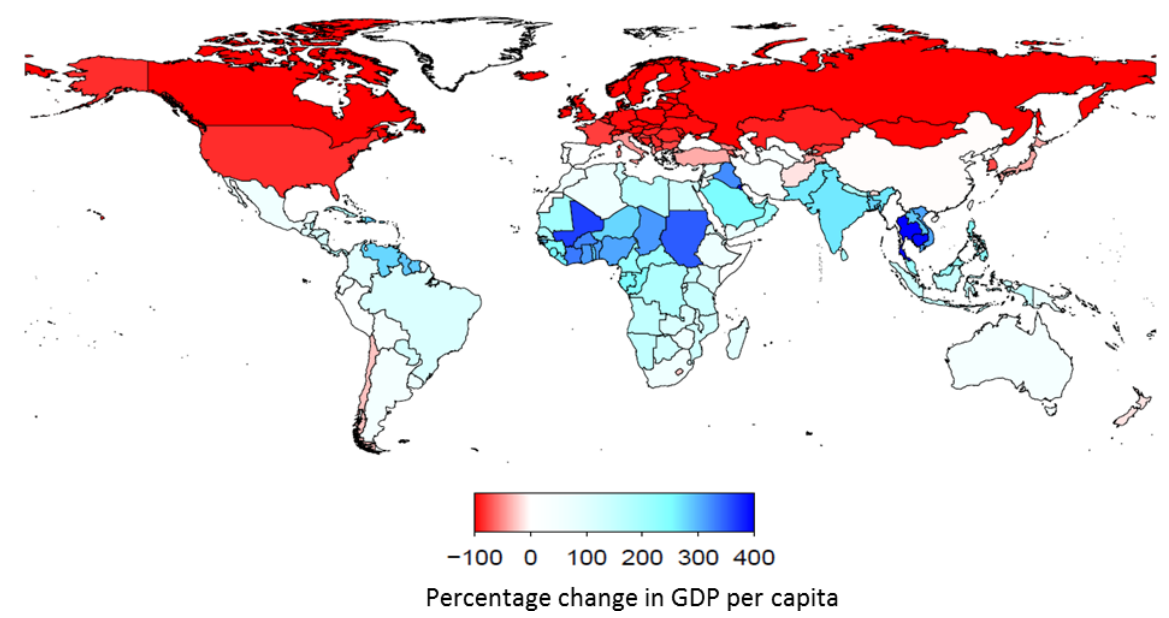

Figure 4. Projected impacts of a $4{ }^{\circ} \mathrm{C}$ global cooling on country GDP per capita in 2100 . Changes are relative to projections without climate change according to SSP5. (a) Changes according to NPS specification (GDP level effects); (b) changes according to BHM specification (GDP growth effects). NB: color scales have different maximum and minimum values for easier visualization.

on both static snow accumulation and ice viscous spreading, would require tens of thousands of years, not a century. Therefore, as a simplification for the sake of the demonstration, we assume the LGM climate equilibrium is reached in 2100, except for the ice sheet thickness and extent as well as associated sea level drop, since the timing is obviously too short. Such a simplification implies some inconsistency, since the LGM climate also depended on the albedo and elevation feedbacks from the ice sheets. We also acknowledge that (1) the response of the Earth system to a forcing that would lead to a $4^{\circ} \mathrm{C}$ cooling in 2100 would be different from the LGM, depending on the type of forcing, and therefore the LGM is not a perfect reverse analog of a future at $+4{ }^{\circ} \mathrm{C}$; (2) it took much more than a century to move from the LGM to the Holocene, our current interglacial period. However, the projected rate of global warming for the RCP8.5 scenario is actually faster than any glacial-interglacial changes that oc- curred naturally during the last 800000 years: about 65 times as high as the average warming during the last deglaciation (Nolan et al., 2018). Besides, the level of warming in 2100 for the RCP8.5 scenario might exceed $4{ }^{\circ} \mathrm{C}$, especially if strong positive feedback loops lead to the crossing of planetary thresholds, hence driving the Earth in a "hothouse" state (Steffen et al., 2018; Schneider et al., 2019). Accordingly, using the LGM-to-present environmental changes as an index of future changes might even be considered conservative.

With these caveats in mind, let us now take a closer look at the most obvious consequences of our scenario for human societies.

Results from climate models show that the surface mass balance of the northern LGM ice sheets was positive over most parts, outside the ablation zones on the edges, with annual accumulation rates of water equivalent of a few tens of centimeters per year (e.g., Calov et al., 2005). Therefore, in 


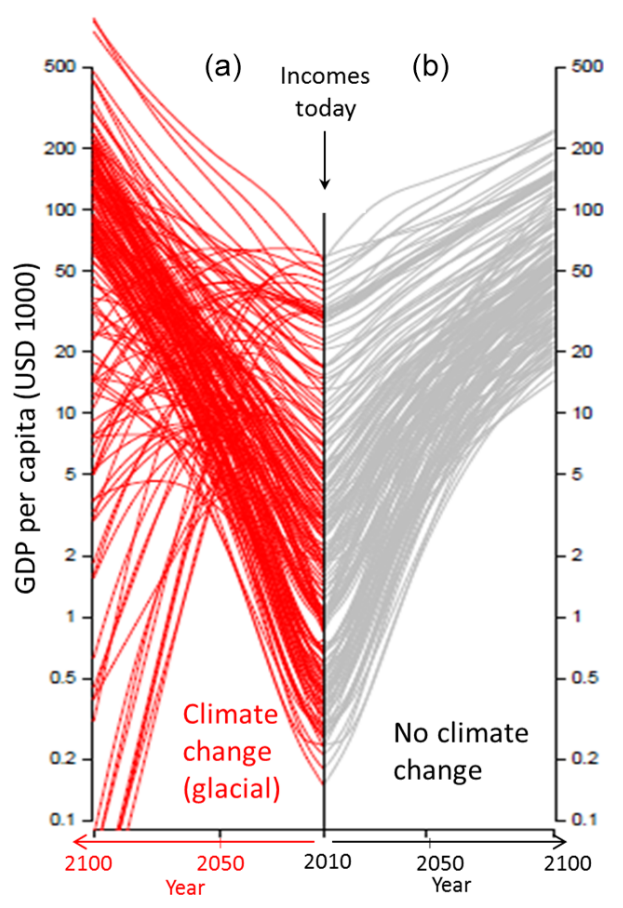

Figure 5. Country-level average income projections with and without temperature effects of a "glacial" climate change. Projections to 2100 according to the SSP5 scenario, assuming high baseline growth and fast income convergence. The center is 2010, and each line is a projection of national income. On the right (grey) are incomes under baseline SSP5 assumptions, and on the left (red) are incomes accounting for nonlinear effects of projected cooling on GDP growth.

our thought experiment, snow accumulation on regions corresponding to the LGM ice sheet extent would reach a few meters at the end of the century. Moreover, in the most central regions, the decrease in the mean annual temperature would be greater than $20^{\circ} \mathrm{C}$ (Fig. 2) and the cold would be hard to cope with. We presume that regions experiencing either such low temperatures and/or being buried under a thick permanent and growing layer of snow would become rather unsuitable for most modern economic activities. The impacted regions would be Canada, Alaska, the Great Lakes region of the United States, the states north of $40^{\circ} \mathrm{N}$ on the east coast of the United States, the Scandinavian countries, the northern part of Ireland and of the British islands, half of Denmark, the northern parts of Poland, the northeast territories of Germany, all of the Baltic countries, and the northeastern part of Russia. We assume that alpine regions that were widely covered by glaciers during the LGM, i.e., Switzerland and half of Austria, would in our scenario also experience several meters of snow accumulation. All these regions would become unsuitable for most of the millions of people who currently live there, and access to their present natural resources would be very difficult, if not impossible. By comparison, nowadays regions with a mean annual temperature below about $5^{\circ} \mathrm{C}$ have a very low population density (Xu et al., 2020). Shipping routes in the North Atlantic would also be disrupted by the southern expansion of sea ice up to $50^{\circ} \mathrm{N}$ in winter (Gersonde and De Vernal, 2013).

In Europe, the mean annual temperature would decrease by $4-8{ }^{\circ} \mathrm{C}$ in the Mediterranean region, by $8-12^{\circ} \mathrm{C}$ over the western, central, and eastern regions, and by more than $12^{\circ} \mathrm{C}$ over northern countries (Fig. 2). For France, for instance, whose current mean annual temperature is about $11^{\circ} \mathrm{C}$, the temperature decrease would thus correspond to a shift to the current mean temperature of northern Finland. Over western Europe, the mean temperature of the coldest month would decrease by $10-20^{\circ} \mathrm{C}$ (Ramstein et al., 2007) and the mean annual precipitation would decrease by about $300 \mathrm{~mm} \mathrm{yr}^{-1}$ (Wu et al., 2007). Forests would be highly fragmented and replaced by steppe or tundra vegetation (Prentice et al., 2011). The southern limit of the permafrost would approximately reach $45^{\circ} \mathrm{N}$, i.e., the latitude of Bordeaux (Vandenberghe et al., 2014). In such a context, maintaining European agriculture at its present state, among other human activities, would be a costly and technically highly demanding challenge. Energy needs for heating would tremendously increase, current infrastructures would be damaged by severe frost, and there is no doubt that Europe would no longer sustain its current population on lands preserved from permanent snow accumulation.

In Asia, similar problems would occur, with a decrease in mean annual temperature between 4 and $8{ }^{\circ} \mathrm{C}$ over most Chinese regions, for instance (Fig. 2). The boreal forest would have vanished and been replaced by steppe and tundra (Prentice et al., 2011). Permafrost would extend in the northeast and North China, up to Beijing, as well as in the west of the Sichuan (Zhao et al., 2014). As a result, rice cultivation in the northern province of Heilongiiang, for instance, which is currently above $20 \times 10^{6} \mathrm{tyr}^{-1}$, i.e., about $10 \%$ of the national production (Clauss et al., 2016), would no longer be possible. Permafrost would not stretch out to the whole densely populated North China Plains, but the cold and dry climate there would nonetheless prevent rice cultivation. The discharge of the Yangtze River at Nanjing would be less than half its present-day value (Cao et al., 2010), questioning current hydroelectricity production. In short, current livelihoods in these regions would no longer be sustainable and the population would probably be much lower than today.

Temperature changes in the tropics would be rather moderate, with a cooling of $2.5-3{ }^{\circ} \mathrm{C}$ (Wu et al., 2007; Annan and Hargreaves, 2013) (Fig. 2). This temperature decrease might be considered good news and is indeed the driver of the GDP increase simulated in tropical countries with both specifications we considered (Fig. 4). However, tropical temperature decrease would come with strong changes in the hydrological cycle, casting some doubts on such an optimistic view. The interannual rainfall variability in East Africa would be reduced (Wolff et al., 2011), but so would be the mean rate; the southwest Indian monsoon system would be significantly 
weaker over both Africa and India (Overpeck et al., 1996); the Sahara and Namib would both expand (Ray and Adams, 2001); annual rainfall over the Amazon basin would strongly decrease (Cook and Vizy, 2006). Compared to their modern extension, the African humid forest area might be reduced by as much as $74 \%$ and the Amazon forest by $54 \%$ (Anhuf et al., 2006).

Globally, the planet would appear considerably more arid (Kageyama et al., 2013; Ray and Adams, 2001; Bartlein et al., 2011). However, the widespread increase in aridity at the LGM is debated since the reduction of the atmospheric demand for evaporation because of lower temperatures could compensate for the precipitation decrease, and drier places in terms of precipitation were not always drier in terms of hydrology (Scheff et al., 2017; McGee, 2020). As already mentioned, glacial vegetation changes were also driven by the decrease in atmospheric $\mathrm{CO}_{2}$, which can bias aridity increase inferred from pollen proxy data. Yet, many places were indeed hydrologically drier at the LGM, including some currently densely populated areas. The southward spread of the extra-arid zone of the Sahara, for instance, is estimated to $300-450 \mathrm{~km}$ (Lioubimtseva et al., 1998). For India, LGM data are rather sparse. Simulation results suggest that there was indeed a large decrease in runoff across monsoonal Asia (Li and Morrill, 2013), in agreement with marine proxy data from the Bay of Bengal, suggesting a reduction in fluvial discharge (Duplessy, 1982). For our scenario, this could mean less flooding during the monsoon season, but also a decrease in water resources during the dry season, in areas where droughts are already an issue. In regions already dry today, like Pakistan and northwestern India, it seems that the climatic conditions would indeed be even more arid (Ansari and Vink, 2007). In Indonesia, LGM climate simulations show a decrease in the precipitation minus evaporation (Scheff et al., 2017), but vegetation changes depend on the location (Dubois et al., 2014). Therefore, for that region, we cannot really infer potential impacts of our glacial scenario for human populations.

The planet would also appear much dustier than today, with probably more frequent and/or intense dust storms that would impact soil erosion rates, health, transportation, and electricity generation and distribution (Middleton, 2017). A potential increase in dust source areas would include northeast Brazil, central and southern South America, southern Africa, central Asia and the Middle East, Australia, China, and southeastern Asia (Harrison et al., 2001).

\section{Discussion}

In summary, our hypothetical ice age scenario corresponds to strong and widespread changes in climatic conditions, not only in temperature, driving major environmental changes (Nolan et al., 2018). In such conditions, neither the results obtained with the BHM and NPS functions nor the baseline GDP scenario (SSP5) appear to be plausible projections.

\subsection{Temperature-GDP level relationship}

We argue that the disruptions in the living conditions on our planet, as briefly described above, cannot plausibly result in a small decrease of less than $2 \%$ in the world potential GDP per capita in 2100, as inferred from the NPS specification. According to these results, Canada would experience only an $8 \%$ decrease in its potential GDP per capita despite its infrastructure being buried under snow, its natural resources being inaccessible or having disappeared, and tremendous frost. Such estimations of climate damage remain utterly unrealistic even if we were ready to consider optimistic adaptation skills of human societies that would prevent them from social calamities such as revolutions, famines, or wars. Our results illustrate how the idea that climate influences only the level of economic output and has no impact on economic growth trajectory is not appropriate for a large climate change. The complete failure of this approach to provide plausible results for a cooling discredits its reliability to account for the impact of a global warming of similar magnitude, which would without doubt drive environmental changes as huge as the one we listed above for the LGM.

\subsection{Temperature-GDP growth relationship}

The BHM specification gives somewhat more plausible results for northern countries, with the projection of a complete collapse of their economies, in agreement with the prospect of permanent snow accumulation, very low temperatures, and large ecosystem shifts. However, we have serious doubts about the (very) large GDP per capita increase predicted in tropical countries given the strong decrease in precipitation in many places and global desert expansion, particularly threatening water resources and agriculture. How can we reconcile, for instance, the projection of a GDP increase of more than $300 \%$ in Sahelian countries with a southward expansion of the Sahara of about $400 \mathrm{~km}$ ? The BHM setup focuses on damage driven by temperature change only (or changes for which temperature is a proxy) and does not take into account precipitation changes for climate change projections. Their study did not find that mean annual precipitation had a significant effect on the economy in the last decades, a result rather surprising considering the strong impacts that droughts and extreme precipitation may have. This could be due to the fact that the mean precipitation at the country scale is not an appropriate variable, since it does not necessarily correctly capture seasonality changes or extreme events, for instance. In any case, should precipitation effects be negligible for the recent past, they cannot be ignored in the case of major hydrological changes that would also drive radical ecological shifts. 
Similarly, the absence of damage in China can hardly be conceptually reconciled with both deserts and permafrost expansion, which should very probably have strong negative impacts on agriculture in the north and northeast of the country, or the strong decrease in fluvial discharge.

Moreover, the complete collapse of (at least) the northern nations, including expected massive migrations of millions of people outside these regions, would be expected to have serious economic and geopolitical consequences at the global scale that we can hardly imagine being very positive. The statistical method of BHM captures the present-day political and economic relationships between countries, but it cannot account for future changes in these relationships, a major deficiency in a globalized world.

It is difficult to imagine how the world could be globally much wealthier than it would have been without such disruptions in climatic and ecological conditions, especially if most places are no longer suitable for agriculture, as may have been the case during the Pleistocene (Richerson et al., 2001). Agriculture may account for only a few percent of GDP in present-day developed countries, but food production is obviously the first need of any society. We therefore conclude that, despite its endeavor toward realism, the BHM function does not provide results more convincing than the NPS one.

\subsection{Cooling vs. warming: symmetry or asymmetry of impacts?}

From a physical point of view, there is no a priori reason to postulate that a global warming and cooling of similar magnitude would have similar huge impacts. However, the symmetry is implicitly assumed by the GDP-temperature relationship itself: it was built on both negative and positive temperature anomalies, and therefore, by design, it cannot be assumed that such a function could provide relevant damage estimates for a warming but not for a cooling (or the other way around). Moreover, when considering some of the most dramatic climate projections for the RCP8.5 scenario at the end of the century, it seems rather plausible that such a warming would have similar strong impacts as a cooling of similar magnitude.

- On the one hand, as discussed in Sect. 5, for our glacial scenario large parts of North America and Europe would become rather unsuitable for a large human population and most modern economic activities. Currently, 37 million people live in Canada and about 30 million in northern Europe, where we can reasonably assume that only a small population could remain. Maintaining a total population of more than 700 million people in Europe despite the extremely cold temperatures in winter is doubtful, even if the number of people that could still live there (probably mostly in southern Europe) remains speculative. Similarly, the north- western part of the Indian Subcontinent would experience extreme desert conditions (Ansari and Vink, 2007), which would have strong negative impacts for the current 70 million inhabitants in the state of Rajasthan.

- On the other hand, for global warming, the number of people currently living in areas that may be exposed to permanent inundation for a sea level rise of $1.46 \mathrm{~m}$ in 2100 has been estimated at 340 million (Kulp and Strauss, 2019), a number that would be further increased for higher sea level rise values (Bamber et al., 2019). But the most alarming projections are maybe the ones concerning future heat stress: according to Mora et al. (2017), temperature and humidity conditions above a potentially deadly threshold for humans could occur nearly year-round in humid tropical areas, including some of the most densely populated areas. How people could adapt to such unprecedented climatic conditions remains an open question.

\subsection{General issues}

Whether temperature changes impact GDP growth or level is actually a debate of little relevance. In both cases, the use of the mean temperature at the country scale as a proxy for climate effects turns out to provide a highly insufficient picture in the case of a large climate change and leads to a large underestimation of the risks to lives and livelihoods.

This failure can be attributed to different issues of such statistical approaches.

- To our knowledge, there are currently no publications on potential issues in the statistical model itself. In this respect, comments made by one anonymous referee regarding stationarity and the use of control variables (see the public discussion of this paper and Sect. B2 of the Supplement of Burke et al., 2015) seem interesting and worth investigating. As these considerations fall outside the scope of this paper, we leave them for further research. Beyond any purely mathematical consideration, it is interesting to note that both BHM and NPS considered only the mean annual temperature and precipitation to build their respective model. Yet, we speculate that these are not good proxies for climatic variables that would have strong economic impacts, such as seasonality, extreme precipitation events, droughts, or heat waves.

- As mentioned in Sect. 2, one of the serious limitations of these statistical approaches is that they rely on climatic variations over space to extrapolate over time. Indeed, BHM argue that, for most countries in their sample, a global warming of $4{ }^{\circ} \mathrm{C}$ takes them out of their own historical range of temperature but that they still remain within the worldwide distribution of historical temperatures. For that reason, they consider there to be 
no extrapolation out of sample for these countries. If a country gets warmer, the economic impacts can be deduced, they assumed, from past observations in another country whose past temperature was similar. Only a few of the hottest countries would reach temperatures outside the worldwide historical range, and for this category they chose not to extrapolate but to cap future temperature at the upper bound observed in the sample period. As already pointed out by Pezzey (2019), such an assumption is actually untestable. One could argue that human adaptation capacities would succeed in maintaining climate-economy equilibrium even in a changing climate. This hypothesis seems doubtful in the case of long-lived infrastructure facing rapid climate change and certainly does not hold for ecosystems, one of the channels through which climate change impacts the economy. Ecosystems simply cannot adapt quickly enough to a global climate change as fast as $+4{ }^{\circ} \mathrm{C}$ in a century. The speed of forest migration, for instance, is a few hundred meters per year (e.g., Brewer et al., 2002), while temperature change in 2100 according to the RCP8.5 scenario would correspond to a displacement of more than $1000 \mathrm{~km}$ of current temperature zones. The ecosystem-climate equilibrium is not valid on the timescale of a century, and therefore we argue that this issue is in itself sufficient for the extrapolation from space to time to be unwarranted.

- BHM and NPS functions are based on economic data from societies adapted to their current environment. The alleged statistical relationship between GDP per capita and temperature is established for stable ecological conditions and is therefore hardly relevant to assess damage to societies that will experience decades of drastically changing climate and ecosystems and that will have to readapt endlessly to ephemeral new living conditions. It should also be stressed that, as illustrated in Burke et al. (2015), the results obtained with their methodology strongly depend on the assumed reference GDP growth rate without climate change. There is evidence that economic growth rates are path-dependent (Bellaïche, 2010); therefore, in this case it makes no sense to apply a correction to a baseline growth rate that remains unaffected by the damage that occurred the previous years.

- What econometrics maybe show is that, for the few last decades, with a still relatively stable climate, interannual weather variability does not have a strong impact on the economy. We cannot extrapolate from this limited sample what would be the consequences of new climatic conditions completely out of sample and never experienced by humans so far, such as those which could occur in the tropical regions for unabated GHG emissions (Mora et al., 2017; Im et al., 2017; Kang and Eltahir, 2018).
- Beyond the issue of the relevance of the use of mean temperature and precipitation changes as proxies for other climatic variables, there are obviously impacts not accounted for (DeFries et al., 2019), such as glacier melting and resulting water challenges once they have vanished, potential tipping points (Lenton et al., 2008; Steffen et al., 2018) such as a rapid melting of the Greenland or Antarctic ice sheet that would trigger fast sea level rise (Sweet et al., 2017), thawing permafrost, stronger tropical cyclones, ocean acidification, and ecosystem shifts. It is therefore very misleading to consider them to allow for the quantification of "climate change" economic damage. At best, they might provide insight on damage for which temperature has historically been a proxy, and this is highly insufficient, conveying a false picture of the potential risks.

\section{Conclusions}

Should GHG emissions continue unabated, the climate change expected for the end of the century will be of similar magnitude as the last deglaciation, which did not occur in a century but in about 10000 years. Such a rapid change has no equivalent in the recent past of our planet, even less so in human history. Trying to establish a robust assessment of future economic damage based on aggregate statistics of a few decades of GDP and climate data, as attempted by econometric approaches, is probably doomed to failure, even more so when considering only mean annual temperature as a proxy for climate change. Such methodologies seem irrelevant for what lies ahead, since they fail to account for the largest potential impacts of climate change, as was already pointed out by DeFries et al. (2019). In order to strengthen this point, we have used an ad absurdum example of a hypothetical return to the climatic and environmental conditions of the LGM by the end of the century, except for the presence of the northern ice sheets and associated sea level drop, corresponding to a global cooling at a speed and magnitude equivalent to what the business-as-usual scenario of the IPCC announces. The comparison between the results obtained with two different statistical temperature-GDP relationships for our scenario and what we know of the Earth during the LGM suggests that both approaches severely underestimate the impact of climate change. We can therefore conclude that temperature only is a very bad proxy to estimate damage due to a major climate change at a country scale or at the global scale and should not be used for that purpose. More generally, several issues inherent to statistical approaches cast strong doubts on potential significant improvement. In this context, empirically estimating the aggregated relationship between economic activity and weather variables to project future damage is at best useless, at least from a policy point of view. Economists should hence refrain from using exist- 
ing statistical damage functions to infer the global impacts of climate change or to compute optimal policy.

To summarize, our work has proven by absurdum the strong limitations of statistically based methods to quantitatively assess future economic damage. In our view, a more modest and realistic ambition could be endorsed by integrated assessment scenarios, namely that of making an educated guess on the lower bound of such damage at regional, rather than global, scales at which the uncertainty surrounding prospective estimations may be more easily dealt with. This alternate kind of approach would be closer to the enumerative one mentioned in Sect. 2. This ideal approach should, however, not merely use sectorial statistical relationships established for the recent past, as is often currently done. They would otherwise underestimate damage just as aggregated statistical methods do. Instead, they should account for tipping points or potential cascading effects and should definitely be consistent with the future described by climate and ecological sciences (IPCC, 2013). But as already pointed out by Pezzey (2019), it is highly probable that high levels of uncertainties will remain and some risks "are currently impossible to assess numerically, which economists need to acknowledge with greater openness and clarity" (DeFries et al., 2019).

Data availability. Data sets can be found in the Supplement.

Supplement. The supplement related to this article is available online at: https://doi.org/10.5194/esd-11-1073-2020-supplement.

Author contributions. MNW designed the study, performed the simulations, and wrote the paper. GG and AG participated in the discussion on the paper content and in the writing of the paper.

Competing interests. The authors declare that they have no conflict of interest.

Acknowledgements. We thank Mikhail Verbitsky and two anonymous reviewers for their comments to improve this paper. We also thank Antonin Pottier for useful comments and discussion on the initial version of this paper.

Review statement. This paper was edited by Michel Crucifix and reviewed by two anonymous referees.

\section{References}

Anhuf, D., Ledru, M.-P., Behling, H., Da Cruz Jr., F., Cordeiro, R., Van der Hammen, T., Karmann, I., Marengo, J., De Oliveira, P., Pessenda, L., Siffedine, A., Albuquerque, A. L., and Da Silva Dias, P. L.: Paleo-environmental change in Amazonian and African rainforest during the LGM, Palaeogeogr. Palaeocl., 239, 510-527, 2006.

Annan, J. D. and Hargreaves, J. C.: A new global reconstruction of temperature changes at the Last Glacial Maximum, Clim. Past, 9, 367-376, https://doi.org/10.5194/cp-9-367-2013, 2013.

Ansari, M. H. and Vink, A.: Vegetation history and palaeoclimate of the past $30 \mathrm{kyr}$ in Pakistan as inferred from the palynology of continental margin sediments off the Indus Delta, Rev. Palaeobot. Palynol., 145, 201-216, 2007.

Bamber, J. L., Westaway, R. M., Marzeion, B., and Wouters, B.: The land ice contribution to sea level during the satellite era, Environ. Res. Lett., 13, 063008, https://doi.org/10.1088/17489326/aac2f0, 2018.

Bamber, J. L., Oppenheimer, M., Kopp, R. E., Aspinall, W. P., and Cooke, R. M.: Ice sheet contributions to future sea-level rise from structured expert judgment, P. Natl. Acad. Sci. USA, 116, 11195-11200, 2019.

Bartlein, P., Harrison, S., Brewer, S., Connor, S., Davis, B., Gajewski, K., Guiot, J., Harrison-Prentice, T., Henderson, A., Peyron, O., Prentice, I. C., Scholze, M., Seppä, H., Shuman, B., Sugita, S., Thompson, R. S., Viau, A. E., Williams, J., and Wu, H.: Pollen-based continental climate reconstructions at 6 and $21 \mathrm{ka}$ : a global synthesis, Clim. Dynam., 37, 775-802, 2011.

Bellaïche, J.: On the path-dependence of economic growth, J. Math. Econ., 46, 163-178, 2010.

Bovari, E., Giraud, G., and Mc Isaac, F.: Coping with collapse: a stock-flow consistent monetary macrodynamics of global warming, Ecol. Econ., 147, 383-398, 2018.

Braconnot, P., Otto-Bliesner, B., Harrison, S., Joussaume, S., Peterchmitt, J.-Y., Abe-Ouchi, A., Crucifix, M., Driesschaert, E., Fichefet, Th., Hewitt, C. D., Kageyama, M., Kitoh, A., Laîné, A., Loutre, M.-F., Marti, O., Merkel, U., Ramstein, G., Valdes, P., Weber, S. L., Yu, Y., and Zhao, Y.: Results of PMIP2 coupled simulations of the Mid-Holocene and Last Glacial Maximum Part 1: experiments and large-scale features, Clim. Past, 3, 261277, https://doi.org/10.5194/cp-3-261-2007, 2007.

Brewer, S., Cheddadi, R., De Beaulieu, J., and Reille, M.: The spread of deciduous Quercus throughout Europe since the last glacial period, Forest Ecol. Manage., 156, 27-48, 2002.

Burke, M., Hsiang, S., and Miguel, E.: Global non-linear effect of temperature on economic production, Nature, 527, 235-239, 2015.

Burke, M., Davis, W. M., and Diffenbaugh, N. S.: Large potential reduction in economic damages under UN mitigation targets, $\mathrm{Na}$ ture, 557, 549-553, 2018.

Calov, R., Ganopolski, A., Claussen, M., Petoukhov, V., and Greve, R.: Transient simulation of the last glacial inception. Part I: glacial inception as a bifurcation in the climate system, Clim. Dynam., 24, 545-561, 2005.

Cao, G., Wang, J., Wang, L., and Li, Y.: Characteristics and runoff volume of the Yangtze River paleo-valley at Nanjing reach in the Last Glacial Maximum, J. Geogr. Sci., 20, 431-440, 2010. 
Carleton, T. and Hsiang, S.: Social and economic impacts of climate, Science, 353, aad9837, https://doi.org/10.1126/science.aad9837, 2016.

Clark, P., Dyke, A., Shakun, J., Carlson, A., Clark, J., Wohlfarth, B., Mitrovica, J., Hostetler, S., and McCabe, A.: The last glacial maximum, Science, 325, 710-714, 2009.

Clauss, K., Yan, H., and Kuenzer, C.: Mapping paddy rice in China in 2002, 2005, 2010 and 2014 with MODIS time series, Remote Sensing, 8, 434, 2016.

Cook, K. and Vizy, E.: South American climate during the Last Glacial Maximum: delayed onset of the South American monsoon, J. Geophys. Res.-Atmos., 111, D02110, https://doi.org/10.1029/2005JD005980, 2006.

Cowling, S. and Sykes, M.: Physiological significance of low atmospheric $\mathrm{CO}_{2}$ for plant-climate interactions, Quatern. Res., 52, 237-242, 1999

Cox, P. M., Betts, R., Collins, M., Harris, P. P., Huntingford, C., and Jones, C.: Amazonian forest dieback under climate-carbon cycle projections for the 21 st century, Theor. Appl. Climatol., 78, 137156, 2004

DeCanio, S.: Economic models of climate change: a critique, Palgrave Macmillan, New York, NY and Houndmills, Basingstoke, Hampshire, 2003.

DeFries, R. S., Edenhofer, O., Halliday, A. N., Heal, G. M., Lenton, T., Puma, M., Rising, J., Rockström, J., Ruane, A., Schellnhuber, H. J., Stainforth, D., Stern, N., Tedesco, M., and Ward, B.: The missing economic risks in assessments of climate change impacts, Grantham Research Institute, London, UK, 2019.

Dell, M., Jones, B., and Olken, B.: Temperature shocks and economic growth: Evidence from the last half century, Am. Econ. J.: Macroecon., 4, 66-95, 2012.

Dietz, S. and Stern, N.: Endogenous growth, convexity of damage and climate risk: how Nordhaus' framework supports deep cuts in carbon emissions, Econ. J., 125, 574-620, 2015.

Diffenbaugh, N. and Burke, M.: Global warming has increased global economic inequality, P. Natl. Acad. Sci. USA, 116, 98089813, 2019.

Dubois, N., Oppo, D. W., Galy, V. V., Mohtadi, M., Van Der Kaars, S., Tierney, J. E., Rosenthal, Y., Eglinton, T. I., Lückge, A., and Linsley, B. K.: Indonesian vegetation response to changes in rainfall seasonality over the past 25,000 years, Nat. Geosci., 7, 513517,2014

Duplessy, J. C.: Glacial to interglacial contrasts in the northern Indian Ocean, Nature, 295, 494-498, 1982.

Fankhauser, S.: The social costs of greenhouse gas emissions: an expected value approach, Energy J., 15, 157-184, 1994.

Gersonde, R. and De Vernal, A.: Reconstruction of past sea ice extent, PAGES News, 21, 30-31, 2013.

Hansen, J., Sato, M., Hearty, P., Ruedy, R., Kelley, M., MassonDelmotte, V., Russell, G., Tselioudis, G., Cao, J., Rignot, E., Velicogna, I., Tormey, B., Donovan, B., Kandiano, E., von Schuckmann, K., Kharecha, P., Legrande, A. N., Bauer, M., and Lo, K.-W.: Ice melt, sea level rise and superstorms: evidence from paleoclimate data, climate modeling, and modern observations that $2{ }^{\circ} \mathrm{C}$ global warming could be dangerous, Atmos. Chem. Phys., 16, 3761-3812, https://doi.org/10.5194/acp16-3761-2016, 2016.

Harrison, S. and Prentice, C.: Climate and $\mathrm{CO}_{2}$ controls on global vegetation distribution at the last glacial maximum: analysis based on palaeovegetation data, biome modelling and palaeoclimate simulations, Global Change Biol., 9, 983-1004, 2003.

Harrison, S., Kohfeld, K., Roelandt, C., and Claquin, T.: The role of dust in climate changes today, at the last glacial maximum and in the future, Earth-Sci. Rev., 54, 43-80, 2001.

Hsiang, S.: Climate econometrics, Annu. Rev. Resour. Econ., 8, 4375, 2016.

Hsiang, S., Kopp, R., Jina, A., Rising, J., Delgado, M., Mohan, S., Rasmussen, D., Muir-Wood, R., Wilson, P., Oppenheimer, M., Larsen,K., and Houser, T.: Estimating economic damage from climate change in the United States, Science, 356, 1362-1369, 2017.

Hughes, T. P., Kerry, J. T.,Álvarez-Noriega, M.,Álvarez-Romero, J. G., Anderson, K. D., Baird, A. H., Babcock, R. C., Beger, M., Bellwood, D. R., Berkelmans, R., Bridge, T. C., Butler, I. R., Byrne, M., Cantin, N. E., Comeau, S., Connolly, S. R., Cumming, G. S., Dalton, S. J., Diaz-Pulido, G., Eakin, C. M., Figueira, W. F., Gilmour, J. P., Harrison, H. B., Heron, S. F., Hoey, A. S., Hobbs, J.-P. A., Hoogenboom, M. O., Kennedy, E. V., Kuo, C.-Y., Lough, J. M., Lowe, R. J., Liu, G., McCulloch, M. T., Malcolm, H. A., McWilliam, M. J., Pandolfi, J. M., Pears, R. J., Pratchett, M. S., Schoepf, V., Simpson, T., Skirving, W. J., Sommer, B., Torda, G., Wachenfeld, D. R., Willis, B. K., and Wilson, S. K.: Global warming and recurrent mass bleaching of corals, Nature, 543, 37300377, 2017.

Im, E.-S., Pal, J. S., and Eltahir, E. A.: Deadly heat waves projected in the densely populated agricultural regions of South Asia, Sci. Adv., 3, e1603322, https://doi.org/10.1126/sciadv.1603322, 2017.

IPCC: Climate change: The IPCC scientific assessment, Mass, Cambridge, 1990.

IPCC: Climate Change 2013: The Physical Science Basis, in: Contribution of Working Group I to the Fifth Assessment Report of the Intergovernmental Panel on Climate Change, edited by: Stocker, T., Qin, D., Plattner, G., Tignor, M., Allen, S., Boschung, J., Nauels, A., Xia, Y., Bex, V., and Midgley, P.: Cambridge University Press, Cambridge, UK and New York, NY, USA, 1535 pp., 2013.

Jolly, D. and Haxeltine, A.: Effect of low glacial atmospheric $\mathrm{CO}_{2}$ on tropical African montane vegetation, Science, 276, 786-788, 1997.

Kageyama, M., Braconnot, P., Bopp, L., Mariotti, V., Roy, T., Woillez, M.-N., Caubel, A., Foujols, M.-A., Guilyardi, E., Khodri, M., Lloyd, J., Lombard, F., and Marti, O.: Mid-Holocene and last glacial maximum climate simulations with the IPSL model: part II: model-data comparisons, Clim. Dynam., 40, 2469-2495, 2013.

Kageyama, M., Braconnot, P., Harrison, S. P., Haywood, A. M., Jungclaus, J. H., Otto-Bliesner, B. L., Peterschmitt, J.-Y., AbeOuchi, A., Albani, S., Bartlein, P. J., Brierley, C., Crucifix, M., Dolan, A., Fernandez-Donado, L., Fischer, H., Hopcroft, P. O., Ivanovic, R. F., Lambert, F., Lunt, D. J., Mahowald, N. M., Peltier, W. R., Phipps, S. J., Roche, D. M., Schmidt, G. A., Tarasov, L., Valdes, P. J., Zhang, Q., and Zhou, T.: The PMIP4 contribution to CMIP6 - Part 1: Overview and overarching analysis plan, Geosci. Model Dev., 11, 1033-1057, https://doi.org/10.5194/gmd-11-1033-2018, 2018. 
Kang, S. and Eltahir, E. A.: North China Plain threatened by deadly heatwaves due to climate change and irrigation, Nat. Commun., 9, 2894, https://doi.org/10.1038/s41467-018-05252-y, 2018.

Kriegler, E., Bauer, N., Popp, A., Humpenöder, F., Leimbach, M., Strefler, J., Baumstark, L., Bodirsky, B., Hilaire, J., Klein, D., Mouratiadou, I., Weindl, I., Bertram, C., Dietrich, J.-P., Luderer, G., Pehl, M., Pietzcker, R., Piontek, F., Lotze-Campen, H., Biewald, A., Bonsch, M., Giannousakis, A., Kreidenweis, U., Müller, C., Rolinski, S., Schultes, A., Schwanitz, J., Stevanovic, M., Calvin, K., Emmerling, J., Fujimori, S., and Edenhofer, O.: Fossil-fueled development (SSP5): an energy and resource intensive scenario for the 21st century, Global Environ. Change, 42, 297-315, 2017.

Kucera, M., Rosell-Melé, A., Schneider, R., Waelbroeck, C., and Weinelt, M.: Multiproxy approach for the reconstruction of the glacial ocean surface (MARGO), Quaternary Sci. Rev., 24, 813819, 2005.

Kulp, S. A. and Strauss, B. H.: New elevation data triple estimates of global vulnerability to sea-level rise and coastal flooding, Nat. Commun., 10, 1-12, 2019.

Lenton, T. M., Held, H., Kriegler, E., Hall, J. W., Lucht, W., Rahmstorf, S., and Schellnhuber, H. J.: Tipping elements in the Earth's climate system, P. Natl. Acad. Sci. USA, 105, 1786-1793, 2008.

Li, Y. and Morrill, C.: Lake levels in Asia at the Last Glacial Maximum as indicators of hydrologic sensitivity to greenhouse gas concentrations, Quaternary Sci. Rev., 60, 1-12, 2013.

Lioubimtseva, E., Simon, B., Faure, H., Faure-Denard, L., and Adams, J.: Impacts of climatic change on carbon storage in the Sahara-Gobi desert belt since the Last Glacial Maximum, Global Planet. Change, 16, 95-105, 1998.

McGee, D.: Glacial-Interglacial Precipitation Changes, Annu. Rev. Mar. Sci., 12, 525-557, 2020.

Middleton, N. J.: Desert dust hazards: A global review, Aeolian Res., 24, 53-63, 2017.

Mora, C., Dousset, B., Caldwell, I. R., Powell, F. E., Geronimo, R. C., Bielecki, C. R., Counsell, C. W. W., Dietrich, B. S., Johnston, E. T., Louis, L. V., Lucas, M. P., McKenzie, M. M., Shea, A. G., Tseng, H., Giambelluca, T. W., Leon, L. R., Hawkins, E., and Trauernicht, C.: Global risk of deadly heat, Nat. Clim. Change, 7, 501-506, 2017.

Newell, R. G., Prest, B. C., and Sexton, S.: The GDP-temperature relationship: implications for climate change damages, Resour. Future Work. Pap., available at: https://media.rff.org/ archive/files/document/file/RFFWP-18-17-rev.pdf (last access: 17 November 2020), 2018.

Nolan, C., Overpeck, J. T., Allen, J. R. M., Anderson, P. M., Betancourt, J. L., Binney, H. A., Brewer, S., Bush, M. B., Chase, B. M., Cheddadi, R., Djamali, M., Dodson, J., Edwards, M. E., Gosling, W. D., Haberle, S., Hotchkiss, S. C., Huntley, B., Ivory, S. J., Kershaw, A. P., Kim, S.-H., Latorre, C., Leydet, M., Lézine, A.-M., Liu, K.-B., Liu, Y., Lozhkin, A. V., McGlone, M. S., Marchant, R. A., Momohara, A., Moreno, P. I., Müller, S., Otto-Bliesner, B. L., Shen, C., Stevenson, J., Takahara, H., Tarasov, P. E., Tipton, J., Vincens, A., Weng, C., Xu, Q., Zheng, Z., and Jackson, S. T.: Past and future global transformation of terrestrial ecosystems under climate change, Science, 361, 920-923, 2018.

Nordhaus, W.: Expert opinion on climatic change, Am. Sci., 82, 45-51, 1994a.
Nordhaus, W. D.: Managing the global commons: the economics of climate change, in: vol. 31, MIT Press, Cambridge, MA, 1994b.

Nordhaus, W. D.: Geography and macroeconomics: New data and new findings, P. Natl. Acad. Sci. USA, 103, 3510-3517, 2006.

Overpeck, J., Anderson, D., Trumbore, S., and Prell, W.: The southwest Indian Monsoon over the last 18000 years, Clim. Dynam., 12, 213-225, 1996.

Peltier, W.: Global glacial isostasy and the surface of the ice-age Earth: the ICE-5G (VM2) model and GRACE, Annu. Rev. Earth Planet. Sci., 32, 111-149, 2004.

Pezzey, J. C.: Why the social cost of carbon will always be disputed, Wiley Interdisciplin. Rev.: Clim. Change, 10, e558, https://doi.org/10.1002/wcc.558, 2019.

Pindyck, R.: Climate change policy: what do the models tell us?, J. Econ. Literat., 51, 860-72, 2013.

Pindyck, R.: The use and misuse of models for climate policy, Rev. Environ. Econ. Policy, 11, 100-114, 2017.

Pottier, A.: Comment les économistes réchauffent la planète, Le Seuil, Paris, 2016.

Prentice, I., Harrison, S., and Bartlein, P.: Global vegetation and terrestrial carbon cycle changes after the last ice age, New Phytol., 189, 988-998, 2011.

Ramstein, G., Kageyama, M., Guiot, J., Wu, H., Hély, C., Krinner, G., and Brewer, S.: How cold was Europe at the Last Glacial Maximum? A synthesis of the progress achieved since the first PMIP model-data comparison, Clim. Past, 3, 331-339, https://doi.org/10.5194/cp-3-331-2007, 2007.

Ray, N. and Adams, J.: A GIS-based vegetation map of the world at the last glacial maximum $(25,000-15,000 \mathrm{BP})$, Internet Archaeol., 11, available at: http://intarch.ac.uk/journal/issue11/ rayadams_toc.html (last access: 17 November 2020), 2001.

Riahi, K., Rao, S., Krey, V., Cho, C., Chirkov, V., Fischer, G., Kindermann, G., Nakicenovic, N., and Rafaj, P.: RCP 8.5 - A scenario of comparatively high greenhouse gas emissions, Climatic Change, 109, 33, 2011.

Richerson, P., Boyd, R., and Bettinger, R.: Was agriculture impossible during the Pleistocene but mandatory during the Holocene? A climate change hypothesis, Am. Antiq., 66, 387-411, 2001.

Ricke, K., Drouet, L., Caldeira, K., and Tavoni, M.: Country-level social cost of carbon, Nat. Clim. Change, 8, 895-900, 2018.

Roson, R. and Van der Mensbrugghe, D.: Climate change and economic growth: impacts and interactions, Int. J. Sustain. Econ., 4, 270-285, 2012.

Scheff, J., Seager, R., Liu, H., and Coats, S.: Are glacials dry? Consequences for paleoclimatology and for greenhouse warming, $\mathrm{J}$. Climate, 30, 6593-6609, 2017.

Schneider, T., Kaul, C. M., and Pressel, K. G.: Possible climate transitions from breakup of stratocumulus decks under greenhouse warming, Nat. Geosci., 12, 163-167, 2019.

Shepherd, A., Ivins, E., Rignot, E., Smith, B., Van Den Broeke, M., Velicogna, I., Whitehouse, P. L., Briggs, K., Joughin, I., Krinner, G., Nowicki, S., Payne, T., Scambos, T., Schlegel, N., Geruo, A., Agosta, C., Ahlstrøm, A., Babonis, G., Barletta, V., Blazquez, A., Bonin, J., Csatho, B., Cullather, R., Felikson, D., Fettweis, X., Forsberg, R., Gallee, H., Gardner, A., Gilbert, L., Groh, A., Gunter, B., Hanna, E., Harig, C., Helm, V., Horvath, A., Horwath, M., Khan, S., Kjeldsen, K. K., Konrad, H., Langen, P., Lecavalier, B., Loomis, B., Luthcke, S., McMillan, M., Melini, D., Mernild, S., Mohajerani, Y., Moore, P., Mouginot, J., Moy- 
ano, G., Muir, A., Nagler, T., Nield, G., Nilsson, J., Noel, B., Otosaka, I., Pattle, M. E., Peltier, W. R., Pie, N., Rietbroek, R., Rott, H., Sandberg-Sørensen, L., Sasgen, I., Save, H., Scheuchl, B., Schrama, E., Schröder, L., Seo, K.-W., Simonsen, S., Slater, T., Spada, G., Sutterley, T., Talpe, M., Tarasov, L., van de Berg, W. J., van der Wal, W., van Wessem, M., Vishwakarma, B. D., Wiese, D., and Wouters, B.: Mass balance of the Antarctic ice sheet from 1992 to 2017, Nature, 558, 219-222, 2018.

Steffen, W., Rockström, J., Richardson, K., Lenton, T. M., Folke, C., Liverman, D., Summerhayes, C. P., Barnosky, A., Cornell, S. E., Crucifix, M., Donges, J. F., Fetzer, I., Lade, S. J., Scheffer, M., Winkelmann, R., and Schellnhuber, H. J.: Trajectories of the Earth System in the Anthropocene, P. Natl. Acad. Sci. USA, 115, 8252-8259, 2018.

Sweet, W. V., Kopp, R. E., Weaver, C. P., Obeysekera, J., Horton, R. M., Thieler, E. R., and Zervas, C.: Global and regional sea level rise scenarios for the United States, Tech. rep. NOS COOPS 083, National Oceanic and Atmospheric Administration, Silver Spring, MD, Maryland, 2017.

Tol, R.: The Economic Impacts of Climate Change, Rev. Environ. Econ. Policy, 12, 4-25, 2018.

Tol, R. S.: Estimates of the damage costs of climate change. Part 1: Benchmark estimates, Environ. Resour. Econ., 21, 47-73, 2002.

Tol, R. S.: The economic effects of climate change, J. Econ. Perspect., 23, 29-51, 2009.

Vandenberghe, J., French, H., Gorbunov, A., Marchenko, S., Velichko, A., Jin, H., Cui, Z., Zhang, T., and Wan, X.: The Last Permafrost Maximum (LPM) map of the Northern Hemisphere: permafrost extent and mean annual air temperatures, 25$17 \mathrm{ka} \mathrm{BP}$, Boreas, 43, 652-666, 2014.
Weitzman, M.: GHG targets as insurance against catastrophic climate damages, J. Publ. Econ. Theory, 14, 221-244, 2012.

Woillez, M.-N., Kageyama, M., Krinner, G., de Noblet-Ducoudré, N., Viovy, N., and Mancip, M.: Impact of $\mathrm{CO}_{2}$ and climate on the Last Glacial Maximum vegetation: results from the ORCHIDEE/IPSL models, Clim. Past, 7, 557-577, https://doi.org/10.5194/cp-7-557-2011, 2011.

Wolff, C., Haug, G., Timmermann, A., Damsté, J., Brauer, A., Sigman, D., Cane, M., and Verschuren, D.: Reduced interannual rainfall variability in East Africa during the last ice age, Science, 333, 743-747, 2011.

Wu, H., Guiot, J., Brewer, S., and Guo, Z.: Climatic changes in Eurasia and Africa at the last glacial maximum and midHolocene: reconstruction from pollen data using inverse vegetation modelling, Clim. Dynam., 29, 211-229, 2007.

Xu, C., Kohler, T., Lenton, T., Svenning, J.-C., and Scheffer, M.: Future of the human climate niche, P. Natl. Acdad. Sci. USA, 117, 11350-11355, 2020.

Zhao, L., Jin, H., Li, C., Cui, Z., Chang, X., Marchenko, S. S., Vandenberghe, J., Zhang, T., Luo, D., Guo, D., Liu, G., and Yi, C.: The extent of permafrost in China during the local Last Glacial Maximum (LLGM), Boreas, 43, 688-698, 2014. 